Solomon's Child 



\section{$W R|T| N G S C \mid E N C E$}

EDITORS Timothy Lenoir and Hans Ulrich Gumbrecht 



\title{
SOLOMON'S CHILD
}

METHOD IN THE EARLY ROYAL SOCIETY OF LONDON

\author{
William T. Lynch
}

Stanford University Press

Stanford, California 
Stanford University Press

Stanford, California

(C) $200 \mathrm{I}$ by the Board of Trustees of the

Leland Stanford Junior University

Printed in the United States of America

Library of Congress Cataloging-in-Publication Data

Lynch, William

Solomon's child : method in the early Royal Society of London /

William T. Lynch.

p. $\quad \mathrm{cm}$. - (Writing science)

Includes bibliographical references and index.

ISBN 0-8047- 329I-4 (acid-free paper)

I. Science-Great Britain-Methodology-History-17th century.

2. Bacon, Francis, I 56I-I626. 3. Royal Society (Great Britain).

I. Title. II. Series.

QI74.8.L96 2OOI
$509.4 I^{\prime} 09$ 'O32- dc2I

200I04I086

This book is printed on acid-free, archival-quality paper.

Original printing $200 \mathrm{I}$

Last figure below indicates year of this printing:

$\begin{array}{llllllllll}\text { I0 } & 09 & 08 & 07 & 06 & 05 & 04 & 03 & 02 & \text { OI }\end{array}$

Typeset at Stanford University Press in Io/13 Sabon 
To Stacy, with all my love 
